\title{
6. The Sex Discrimination Act: Advancing Gender Equality and Decent Work?
}

\author{
Sara Charlesworth
}

This chapter starts with a brief overview of the main Australian regulatory measures that address sex/gender (in)equality in employment. It argues that a major constraint on the influence of the Sex Discrimination Act 1984 (SDA) on the conditions of women's employment has been its effective separation from industrial relations law. This has made it difficult to conceive of sex discrimination as a mainstream employment issue and means that the gender equality impact of industrial relations regulationreflected in classification structures, bargaining provisions and workingtime arrangements - remains invisible. The chapter weighs up the potential of the decent work agenda first proposed by the International Labour Organisation (ILO) and the ILO's framing of gender equality as being 'at the heart of decent work' as the basis for a more effective and integrated policy and regulatory framework.

\section{Introduction}

With the regulatory and institutional basis for regulation in the area of gender equality in employment the subject of various inquiries and of recent legislative reform, it is opportune not only to reflect on where we have been over the past 25 years but to imagine where we might go in the future.

In her chapter, Beth Gaze highlights the limited impact of the Sex Discrimination Act 1984 (Cth) (SDA) on workforce practices. In this chapter, I focus more broadly on regulation in the area of paid employment. The persistence of gender inequality in employment is often seen as due to the ineffectiveness of the SDA and other state-based anti-discrimination laws. As set out below, however, at the federal level in Australia, there are three quite distinct approaches in employment regulation to eliminating discrimination against women. These include the use of specific sex discrimination provisions in the SDA, the implementation of affirmative action provisions initially in the Affirmative Action (Equal Opportunity for Women) Act 1986 (Cth) and then in the Equal Opportunity for Women in the Workplace Act 1999 (Cth), and the prohibition 
of sex and other forms of discrimination in industrial relations law. I argue that the historical separation of anti-discrimination provisions from industrial relations law and the sidelining of discrimination measures within the industrial relations jurisdiction make it difficult both to conceive of sex discrimination as a mainstream industrial relations issue and to render problematic the gender equality impact of industrial relations regulation. Further, I argue that the success of any legislative action to prevent sex discrimination and advance gender equality in employment needs an integrated regulatory and policy framework. To that end, I want to canvass the potential of the 'decent work' agenda first proposed by the International Labour Organisation (ILO) as the basis for a recasting of gender inequality as a mainstream industrial relations concern.

\section{Gender Equality and Australian Employment Regulation}

I begin by reflecting on the main regulatory strategies in Australian employment regulation for dealing with gender inequality in employment drawing on existing critiques and empirical studies.

\section{The Anti-Discrimination Approach}

While prompted by Australia's ratification of the Convention on the Elimination of All Forms of Discrimination Against Women (CEDAW), the SDA drew on a more formal conception of gender equality, constituting the problem it addresses as unequal opportunity measured in terms of 'less favourable' treatment where women and men are similarly situated. This comparator conception takes the male pattern of life as the norm and does not tackle deep-rooted causes of inequality, including the gender division of labour. ${ }^{1}$

Notwithstanding the successes of the SDA, which have been outlined in other chapters, particularly in the normative role it has played and in redress for individual women, close analysis of case law has highlighted the narrowness and complexity of the $S D A$ 's direct and indirect discrimination provisions, which together with its individual complaints-based model and ineffectual enforcement processes have emerged as major structural problems. ${ }^{2}$ All these problems are exacerbated by the increasingly narrow judicial interpretation of

1 Sylvia Walby, Gender (In) Equality and the Future of Work, Equal Opportunities Commission, Manchester, 2007.

2 See Rosemary Hunter, 'The Mirage of Justice: Women and the Shrinking State' (2002) 16 Australian Feminist Law Journal 53; Beth Gaze, 'The Sex Discrimination Act after Twenty Years: Achievements, 
anti-discrimination statutes and of the international law on which they draw. ${ }^{3}$ Empirical studies of the operation of the $S D A$ suggest its implementation is also flawed-highlighted by growing formalism and a 'creeping legalism', with a concentration on procedural fairness that ignores the power disparity between complainants and respondents, as well as a more time-consuming and less transparent conciliation process than has historically been the case in the industrial relations jurisdiction. ${ }^{5}$ Problems with legislative awareness and enforcement have also emerged in specific areas such as sexual harassment and pregnancy discrimination. ${ }^{6}$

The profound changes wrought by globalisation and the deregulation of national labour markets have also contributed to newer forms of gender inequality, which were not envisaged when the SDA was first enacted. The move to the new economy with its reliance on 'flexible' labour has brought with it not only increased demands for women workers, particularly in the service sector, but also risk, uncertainty and underemployment for those who fall outside traditional models of employment regulation. ${ }^{7}$ The growth of nonstandard and precarious employment, individualised work relationships and the decline of union coverage and influence impact disproportionately on women, particularly where employment rights remain based on the dominant male, fulltime, permanent job paradigm. ${ }^{8}$

\footnotetext{
Disappointments, Disillusionment and Alternatives' (2004) 19 University of New South Wales Law Journal Forum 57; Margaret Thornton, 'Auditing the Sex Discrimination Act' in Marius Smith (ed.), Human Rights 2004: The Year in Review, Castan Centre for Human Rights Law, Monash University, Melbourne, 2005.

3 Beth Gaze, 'Context and Interpretation in Anti-Discrimination Law' (2002) 26 Melbourne University Law Review 325; Belinda Smith, 'From Wardley to Purvis - How Far has Australian Anti-Discrimination Law Come in 30 Years?' (2007) Australian Journal of Labour Law 21.

4 Margaret Thornton, The Liberal Promise: Anti-Discrimination Legislation in Australia, Oxford University Press, UK, 1990.

5 Rosemary Hunter and Alice Leonard, The Outcomes of Conciliation in Sex Discrimination Cases, Working Paper No. 8, Centre for Employment and Labour Relations Law, Faculty of Law, The University of Melbourne, Vic., 1995; Anna Chapman, 'Discrimination Complaint-Handling in NSW: The Paradox of Informal Dispute Resolution' (2000) 22 Sydney Law Review 321; Sara Charlesworth, 'The Overlap of the Federal Sex Discrimination and Industrial Relations Jurisdictions: Intersections and Demarcations in Conciliation' (2003) 6 Australian Journal of Labour Economics 559; Thornton, 'Auditing the Sex Discrimination Act'.

6 Human Rights and Equal Opportunity Commission, Sexual Harassment: Serious Business. Results of the 2008 Sexual Harassment National Telephone Survey, Human Rights and Equal Opportunity Commission, Sydney, 2008; Paula McDonald, Sandra Backstrom and Kerriann Dear, ‘Reporting Sexual Harassment: Claims and Remedies' (2008) 46 Asia Pacific Journal of Human Resources 173; Sara Charlesworth and Fiona Macdonald, 'The Unpaid Parental Leave Standard: What Standard?', Refereed Proceedings of the 21 st Conference of Association of Industrial Relations Academics of Australia and New Zealand, Melbourne, 6-8 February 2008. 7 Leah Vosko, "Decent Work": The Shifting Role of the ILO and the Struggle for Global Social Justice' (2002) 2 Global Social Policy 19; Iain Campbell, 'Australia: Institutional Changes and Workforce Fragmentation' in Sangheon Lee and Francois Eyraud (eds), Globalization, Flexibilization and Working Conditions in Asia and the Pacific, Chandros Publishing, Oxford, 2008.

8 Judy Fudge and Rosemary Owens, Precarious Work, Women and the New Economy: The Challenge to Legal Norms, Hart Publishing, Oxford, 2006.
} 


\section{The Human Resource Management Approach}

As outlined in earlier chapters, the positive action provisions in the original Sex Discrimination Bill were sheared off into the separate Affirmative Action (Equal Opportunity for Women) Act 1986 (Cth) (AAA). Despite the potential of the original provisions to encourage action at the enterprise level, implementation of this regulation and its weakening of the Equal Opportunity for Women in the Workplace Act 1999 (EOWWA) reflect what is arguably a human resource management approach to improving equal employment opportunity (EEO) for women through voluntary action by large employers. The implementation of the $A A A$ and the EOWWA has relied on the individualised human resource management discourse of 'diversity' that implicitly undermines the regulation's mandate to address structural discrimination. ${ }^{9}$

In the past decade in particular, voluntary action through best practice was promoted by the Howard Government - in effect substituting for any regulatory action to improve EEO. Paid maternity leave is a case in point. The few existing studies of the impact of the $A A A / E O W W A$ on organisational practice suggest there is little relationship between mandatory reporting by organisations on basic indicators and the achievement of positive organisational outcomes for women. ${ }^{10}$ This is not surprising as compliance with the regulation is based on the submission of reports rather than action taken. Studies drawing on data from organisational reports paint a mixed picture of the impact of $A A A / E O W W A$ regulation, suggesting some correlation between gender-specific human resource management strategies and EEO structures and increases of women in management positions yet little organisational action in the areas of recruitment and the promotion of women. ${ }^{11}$ Industry-specific and organisational studies reveal little connection made between conditions of employment and EEO/ diversity action with a striking lack of interaction between $A A A / E O W W A$ regulation and enterprise bargaining in most large workplaces. ${ }^{12}$

\footnotetext{
9 Carol Bacchi, 'The Seesaw Effect: Down Goes Affirmative Action, Up Comes Workplace Diversity' (2000) 5 Journal of Interdisciplinary Gender Studies 64.

10 Alison Sheridan, 'Affirmative Action in Australia-Employment Statistics can't tell the whole Story' (1995) 10 Women in Management Review 26; Valarie Braithwaite, 'The Australian Government's Affirmative Action Legislation: Achieving Social Change through Human Resource Management' (1993) 15 Law and Policy 322; Glenda Strachan and Erica French, 'Equal Opportunity: Disentangling Promise from Achievement', Proceedings of the Gender, Work and Organisation: 5th Biennial International Interdisciplinary Conference, Keele University, UK, 2007, pp. 1-22.

11 Erica French, 'Approaches to Equity Management and their Relationship to Women in Management' (2001) 12 British Journal of Management 267; Strachan and French, 'Equal Opportunity'.

12 John Burgess and Glenda Strachan, 'Equal Employment Opportunity, Employment Restructuring and Enterprise Bargaining: Complementary or Contradictory?' (1998) 3 Journal of Interdisciplinary Gender Studies 23; Glenda Strachan and John Burgess, 'W(h)ither Affirmative Action Legislation in Australia?' (2000) 5 Journal of Interdisciplinary Gender Studies 46; Strachan and French, 'Equal Opportunity'; Sara Charlesworth, Philippa Hall and Belinda Probert, Drivers and Contexts of Equal Employment Opportunity and Diversity Action in Australian Organisations, RMIT Publishing, Informit E-library, Melbourne, 2005.
} 
I believe that, apart from its limited effect on systemic discrimination within organisations, the enthusiastic promotion of a short-term business case for EEO as part of this human resource management approach to the implementation of the $A A A / E O W W A$ has in fact done very real damage to the pursuit of gender equality in Australia. Its promise that advancing women is good for the business bottom line, assumes, as Sandra Fredman argues, the business interests of employers are compatible with EEO and indeed the good of the business will further the good of all. ${ }^{13}$ The business case thus creates the space for inaction. Further, it hides the business case for unequal opportunity-reflected most tangibly in the gender pay gap - and contributes to a privileging of the rights of business over the rights of women workers to EEO both in public discourse and policy responses.

\section{The Industrial Relations Approach}

Sex discrimination was first recognised in the federal industrial relations jurisdiction in the Industrial Relations Act 1988 (Cth) with the requirement that the Australian Industrial Relations Commission (AIRC) take account of the principles embodied in the SDA. In 1994, further amendments required the AIRC to ensure that labour standards met Australia's international obligations, such as those imposed under the Convention on the Elimination of All Forms of Discrimination Against Women (CEDAW). ${ }^{14}$ The AIRC was also charged with the responsibility to help prevent and eliminate discrimination on various grounds, including on the basis of sex, sexual preference, family responsibilities and pregnancy. These amendments also opened the way for the pursuit of individual claims by employees and explicitly proscribed termination of employment on discriminatory grounds. While these provisions have contributed to important improvements in standards around carers and unpaid parental leave, they have had little practical impact on the fundamental regulation of the employment relationship, particularly in terms of classification structures, wage rates and both enterprise and individual bargaining. This is perhaps unsurprising. The past two decades have seen the erosion of the standard employment relationship (SER) with a growth of temporary and part-time work. The SER, like the 'ideal worker' norm, was based on a concept of full-time permanent waged work with regulation of its basic conditions such as working time and wages by labour law and/or collective agreement. ${ }^{15}$ In Australia, however, as in many other developed countries, what Leah Vosko refers to as 'SER-centrism' continues to permeate the regulation of work. ${ }^{16}$ That is, the greater the deviation from the

\footnotetext{
13 Sandra Fredman, Discrimination Law, Oxford University Press, UK, 2005, p. 25.

14 Industrial Relations Reform Act 1993 (Cth). The amendments took effect in March 1994.

15 Gerhard Bosch, 'Towards a New Standard Employment Relationship in Western Europe?' (2004) 42 British Journal of Industrial Relations 617.

16 Leah Vosko, Precarious Employment and the Problem of SER-Centrism: Regulating for 'Decent Work', Paper given to the Regulating for Decent Work-Innovative Labour Regulation in a Turbulent World Conference, International Labour Organisation, Geneva, 8 July 2009.
} 
standard employment relationship, such as the part-time and casual employment in which a large proportion of Australian women workers are engaged, the less protection there is for workers.

There is a rich vein of empirical studies on the gendered impact of industrial relations regulation on pay inequity and the failure of federal industrial relations regulation to address it, ${ }^{17}$ on the concentration of women in precarious work, ${ }^{18}$ on the regulatory exclusion of groups of women such as outworkers ${ }^{19}$ and on Australia's gendered and polarised working-time regime. ${ }^{20}$ One focus of research has been on the more limited access many women have to so-called 'familyfriendly' arrangements through industrial relations mechanisms such as awards and enterprise agreements because of their location in poor-quality jobs. ${ }^{21}$ Changes in industrial relations regulation in the past 15 years have prompted the analysis of the gendered impact of enterprise bargaining, ${ }^{22}$ of individualised workplace agreements ${ }^{23}$ and of the far-reaching changes introduced through the WorkChoices amendments to the Workplace Relations Act 1996 (Cth) (WRA). ${ }^{24}$

17 Gillian Whitehouse, 'Recent Trends in Pay Equity: Beyond the Aggregate Statistics' (2001) 43 Journal of Industrial Relations 66; Alison Preston and Gillian Whitehouse, 'Gender Differences in Occupation of Employment within Australia' (2004) 7 Australian Journal of Labour Economics 309; Alison Preston and Therese Jefferson, 'Trends in Australia's Gender Wage Ratio' (2007) 18 Journal of Labour and Industry 69; Meg Smith and Michael Lyons, '2020 Vision or 1920s Myopia? Recent Developments in Gender Pay Equity in Australia' (2007) 13 International Employment Relations Review 27.

18 Rosemary Owens, 'Decent Work for the Contingent Workforce in the New Economy' (2002) 15 Australian Journal of Labour Law 209; Fudge and Owens, Precarious Work; Iain Campbell, Gillian Whitehouse and Janine Baxter, 'Australia: Casual Employment, Part-time Employment and the Resilience of the Male Breadwinner Model' in Leah Vosko, Martha MacDonald and Iain Campbell (eds), Gender and the Contours of Precarious Employment, Routledge, London.

19 Rosemary Owens, 'The Peripheral Worker: Women and the Legal Regulation of Outwork' in Margaret Thornton (ed.), Public and Private: Feminist Legal Debates, Oxford University Press, Melbourne, 1995.

20 Barbara Pocock, The Work-Life Collision: What Work is doing to Australians and what to do about it, Federation Press, Sydney, 2003; Campbell, 'Australia'.

21 John Buchanan and Louise Thornthwaite, Paid Work and Parenting: Charting a New Course for Australian Families, Australian Centre for Industrial Relations Research and Training, Sydney, 2001; Jenny Chalmers, Iain Campbell and Sara Charlesworth, 'Part-Time Work and Caring Responsibilities in Australia: Towards an Assessment of Job Quality' (2005) 15 Labour \& Industry 41.

22 Laura Bennett, 'Women and Enterprise Bargaining: The Legal and Institutional Framework' (1994) 36 Journal of Industrial Relations 191; Philippa Hall and Di Fruin, 'Gender Aspects of Enterprise Bargaining: The Good, the Bad and the Ugly' in D. E. Morgan (ed.), Dimensions of Enterprise Bargaining and Organizational Relations, UNSW Studies in Australian Industrial Relations, No. 36, University of New South Wales, Sydney, 1994; John Burgess, Paul Keogh, Duncan Macdonald, G. H. Morgan, Glenda Strachan and Suzanne Ryan, Enterprise Bargaining in Three Female Dominated Workplaces in the Hunter, Employment Studies Research Paper No. 23, University of Newcastle, NSW, 1996; Sara Charlesworth, Stretching Flexibility: Women and Working Time Arrangements in Enterprise Bargaining, Human Rights and Equal Opportunity Commission, Sydney, 1996; Meg Smith and Peter Ewer, The Position of Women in the National Training Reform Agenda and Enterprise Bargaining, Department of Education, Employment and Training, Australian Government Printing Service, Canberra, 1995.

23 John Burgess, Anne Sullivan and Glenda Strachan, 'Australian Workplace Agreements, EEO and Family Friendly Arrangements in the Retail Sector' (2004) 4 Employment Relations Record 61.

24 Barbara Pocock, Jude Elton, Alison Preston, Sara Charlesworth, Fiona Macdonald, Marian Baird, Rae Cooper and Bradon Ellem, 'The Impact of "Work Choices" on Women in Low paid Employment in Australia: A Qualitative Analysis' (2008) 50 Journal of Industrial Relations 475; David Peetz, 'Collateral Damage: Women and the WorkChoices Battlefield' (2007) 33 Hecate 61. 
While the lack of fit between the reality of many women's lives and industrial relations regulation and policy modelled around the 'ideal worker' has been highlighted in these studies, there remains almost a wilful blindness in the industrial relations jurisdiction to the role of classification structures, workingtime provisions and enforcement in the persistence of gender inequality. Indeed, the view that discrimination in employment has little to do with such matters was highlighted by the AIRC last year, when it decided to remove the antidiscrimination clause in awards from the new 'modern awards' on the grounds that 'discrimination is the subject of legislative regulation elsewhere' ${ }^{25}$

\section{Separation of Industrial Relations and Anti- Discrimination Regulation}

In Australia, there is some overlap between anti-discrimination and industrial relations provisions, and the (largely unsuccessful) pursuit of equal remuneration has occurred within the industrial relations jurisdiction. A practical and symbolic divide between two very different regulatory domains remains, ${ }^{26}$ however, as we see in the AIRC's approach to award modernisation.

While employment remains the overwhelming area in which inquiries and formal complaints are made under the $S D A,{ }^{27}$ it remains on the periphery of mainstream employment regulation in practical and policy terms and in terms of envisioning alternatives. ${ }^{28}$ This means that sex discrimination, involving, for example, sexual harassment and pregnancy discrimination, has not been seen as a mainstream employment issue. Further, the gender equality impact of industrial relations regulation - such as the regulation of classification structures, bargaining provisions and working-time arrangements-remains invisible. As Jill Murray argues, pre-existing laws act as a constraining mechanism that limits the choices available to those with the power to shape employment laws. ${ }^{29}$ Perhaps more importantly, they constrain our imagination as to what might be.

\footnotetext{
25 Australian Industrial Relations Commission, Statement of the Full Bench, 12 September 2008 [2008] AIRCFB 717, at Clause 33.

26 Charlesworth, 'The Overlap of the Federal Sex Discrimination and Industrial Relations Jurisdictions' 559.

27 Data show that in 2007-08, 87 per cent of formal complaints lodged under the SDA were in the area of employment. Human Rights and Equal Opportunity Commission, Annual Report 2007-2008, Human Rights and Equal Opportunity Commission, Sydney, 2008.

28 This is reflected in the report of the senate inquiry into the effectiveness of the SDA, in which the Workplace Relations Act 1996 and the (then) Fair Work Australia Bill 2008 were referred to only in passing and not at all in any of the report's 43 recommendations, despite their relevance to many of the issues raised in the report - from workers with family responsibilities to pay inequity. Senate Standing Committee on Legal and Constitutional Affairs 2008, Report on the Effectiveness of the Commonwealth Sex Discrimination Act 1984 in Eliminating Discrimination and Promoting Gender Equality, Parliament of Australia, Canberra.

29 Jill Murray, Working Conditions Laws in an Integrating World Project: Australia, Unpublished paper prepared for the International Labour Organisation 2009.
} 


\section{So Where to Now?}

At the current time, we are in a state of flux, both in terms of proposed and likely legislative changes and institutionally. To date, there has been only a limited government response to the relatively modest recommendations coming out of the senate inquiry into the effectiveness of the $S D A$ made last year, ${ }^{30}$ or to the more far-reaching recommendations of the 2010 report from the House of Representatives inquiry into pay equity and related matters. ${ }^{31}$ The KPMG consultation report on the review of the EOWWA and its Agency for the Federal Office for Women has just been released..$^{32}$ There could be some pressure on the federal government to renovate the basic architecture of the SDA and the EOWWA and to rethink some of the links between industrial relations and antidiscrimination regulation, including positive action. The industrial relations regulatory and institutional arrangements are more settled with the enactment of the Fair Work Act 2009 (Cth) (FWA). Some of the changes in the new FWA suggest that discrimination issues will have a more important place than before in the mainstream employment arena. The Act provides strengthened equal remuneration provisions, a low-paid enterprise bargaining stream and a potentially useful framing of discrimination as 'adverse action'. The Office of the Fair Work Ombudsman has recently set up an anti-discrimination compliance unit. Indeed, if relevant recommendations of the Senate Pay Equity Inquiry are taken up we could yet see a specialist Pay Equity Unit and a Deputy Commissioner for Pay Equity within Fair Work Australia.

Nevertheless, the continuing dominance of the male breadwinner model in the gendered architecture of the 10 National Employment Standards (NES) and draft modern awards - which together are to provide the new safety net for workersis striking. Workers who are employed on a casual basis and/or who have less than 12 months service - workers who are more likely to be women ${ }^{33}$ - are effectively excluded from a number of the standards. And in terms of enforcement, the FWA specifically prevents workers from pursing a breach of the NES rights to request flexible work arrangements and an extension of unpaid parental leave. ${ }^{34}$

\footnotetext{
30 Sex Discrimination Amendment Bill 2010 (Cth).

31 House of Representatives Standing Committee on Employment and Workplace Relations, Making it Fair: Pay Equity and Associated Issues related to Increasing Female Participation in the Workforce, Commonwealth of Australia, Canberra, 2009.

32 KPMG, Review of the Equal Opportunity for Women in the Workplace Act 1999. Consultation Report, KPMG, Melbourne, 2010. The KPMG report uses a rather curious 'weighting' of submissions reporting the percentage in favour of particular changes to both the EOWWA and the agency that implements it, rather than engaging with the merits or substance of the arguments.

33 Australian Bureau of Statistics, Australian Labour Market Statistics, July 2009, Cat. No. 6105, Australian Bureau of Statistics, Canberra, 2009.

34 Sections 739(2) and 740(2) of the Fair Work Act provide there can be no determination of whether an employer had reasonable business grounds for refusing a request, unless the employer has specifically consented in an enterprise or other agreement.
} 
In the exposure drafts of 'modern' awards, we see the reproduction of gendered working-time arrangements in male and female-dominated industries, which underpin the relatively poorer quality work available in the latter. ${ }^{35}$

The limited effectiveness of anti-discrimination law in addressing such entrenched structures has led in many countries to a rethinking of the traditional antidiscrimination framework with regulatory proposals for broader conceptions of equality and for positive action ${ }^{36}$ and a more comprehensive implementation of the widely ratified CEDAW. ${ }^{37}$ Recent renovations of equality regulation in the United Kingdom hold promise, for example, in re-conceiving gender inequality in employment in human rights terms. ${ }^{38}$ It remains unclear, however, whether and how such conceptions will affect mainstream employment regulation or indeed its implementation at the labour market, industry and workplace levels.

\section{A Decent Work Regulatory and Policy Framework}

One innovation I believe could be fruitful is the decent work agenda first proposed by the ILO. Changes in the nature and regulation of work have led to increasing international attention to the dimensions of quality or decent work. ${ }^{39}$ The concept of quality or decent work - which goes to the nature and content of jobs - is a broad one that has not always been gender sensitive. ${ }^{40}$ There is, however, growing recognition of the importance of a gender analysis of job

\footnotetext{
35 For example, a comparison of the exposure drafts of the Metals Award (Exposure Draft of the Manufacturing and Associated Industries and Occupations Award, <http://www.airc.gov.au/awardmod/ databases/metal/Modern/PR988376.doc $>$ ) and the Community Services Award (Exposure Draft of the Social, Community, Home Care and Disability Services Industry Award, <http://www.airc.gov.au/awardmod/ databases/social/Exposure/social.doc $>$ ) shows the maintenance of significant differences in the span of hours provisions and access to penalty rates for work outside these hours, the rights to overtime for part-time workers, as well as more limited classification structures for the community services occupational groups.

36 Joanne Conaghan, 'Intersectionality and UK Equality Initiatives' (2007) 23 South African Journal on Human Rights 317; Sandra Fredman, 'Changing the Norm: Positive Duties in Equal Treatment Legislation' (2005) 12 Maastricht Journal of European and Comparative Law 369.

37 Rikki Holtmaat and Christa Tober, 'CEDAW and the European Union's Policy in the Field of Combating Gender Discrimination' (2005) 12 Maastricht Journal of European and Comparative Law 399.

38 Sandra Fredman, Human Rights Transformed: Positive Duties and Positive Rights, Oxford University Press, UK, 2008.

39 See, for example: Sangheon Lee, Deirdre McCann and John Messenger, Working Time Around the World: Trends in Working Hours, Laws, and Policies in a Global Comparative Perspective, Routledge, Oxford, 2004; Francis Green, Demanding Work: The Paradox of Job Quality in the Affluent Economy, Princeton University Press, NJ, 2005; Mark Smith, Brendan Burchell, Colette Fagan and Catherine O'Brien, 'Job Quality in Europe' (2008) 39 Industrial Relations Journal 586.

40 Francis Green describes job quality as constituted by 'the set of work features which foster the wellbeing of the worker' (see Demanding Work, p. 9). Green focuses on the specific aspects of a job including skill, effort (including work intensity), job control and discretion, wages and risk (in respect of both job security and health and safety). Other approaches employ a broader lens and measure aspects such as labour market status, intrinsic and extrinsic job characteristics, job satisfaction and employee wellbeing, incorporating an assessment not only of the aspects of job quality but also of the outcomes for employees (see Graham Lowe, 21st Century Job Quality: Achieving What Canadians Want, Research Report W/37 Work and Learning, Canadian Policy Research Networks, Toronto, 2007).
} 
quality, with a recent study indicating that gender, along with occupational status and job characteristics such as working time and sector (status and characteristics that are themselves highly gendered in the Australian context), has more influence on an individual's job quality than the country or national model in which they are situated. ${ }^{41}$ Growing attention is also being paid to the roles of national and international mechanisms aimed at improving the conditions of work. ${ }^{42}$ At the international institutional level, both the European Commission (EC) and the ILO have focused on the development of separate agendas around quality or decent work. The ILO's conception of decent work, which built on the ILO Declaration on Fundamental Principles and Rights at Work, was first formally elaborated in 1999 as involving

opportunities for work that is productive and delivers a fair income, security in the workplace and social protection for families, better prospects for personal development and social integration, freedom for people to express their concerns, organize and participate in the decisions that affect their lives and equality of opportunity and treatment for all women and men. ${ }^{43}$

This conception of decent work offers a valuable alternative to the traditional framing of most contemporary employment regulation. It moves beyond the regulatory norm of the standard employment relationship, which excludes so many women. ${ }^{44}$ And the attainment of gender equality has a more central and less contingent place than in the European Commission's 'more and better' jobs agenda, ${ }^{45}$ illustrated in the ILO's 2008-09 campaign around 'gender equality at the heart of decent work'. This framing of gender equality in the context of decent work, according to the ILO,

embraces equality of opportunity and treatment, equality of remuneration and access to safe and healthy working environments, equality in association and collective bargaining, equality in obtaining meaningful career development, maternity protection, and a balance between work and home life that is fair to both men and women. ${ }^{46}$

\footnotetext{
41 Smith et al., 'Job Quality in Europe'.

42 Vosko, 'Decent Work'; Mary Cornish, Ending Labour Market Gender Discrimination- Bringing Gender Mainstreaming into Parliamentary Laws and Institutions, Presentation to Women \& Work Conference of International Parliamentary Unions, Geneva, 6 December 2007.

43 International Labour Organisation, Decent Work: A Report of the Director-General, 89th Session of the International Labour Organisation, Geneva, 1999.

44 Vosko, 'Decent Work'; Mary Cornish, 'Closing the Global Gender Pay Gap: Securing Justice for Women's Work' (2007) 28 Comparative Labour Law and Policy Journal 219.

45 Alexandra Scheele, 'Gender and the Quality of Work: An Overview of European and National Approaches' (2007) 13 Transfer 595.

46 International Labour Organisation, $A B C$ of Women Workers' Rights and Gender Equality, Second edition, International Labour Organisation, Geneva, 2007, p. 92.
} 
The attainment of gender equality, then, sits squarely in mainstream employment regulation. Importantly, in its inclusion of personal development and social integration, it recognises the relationship between paid work and unpaid work as critical for the realisation of gender equality. The concept of decent work thus has potential to move beyond the confines of the workplace to 'work's place' in personal, social and economic life. ${ }^{47}$

There are of course inherent tensions and limitations in the decent work agenda ${ }^{48}$ - not least that in practice it is directed mainly at developing countries. In Australia, the aspirations of the decent work agenda have not yet been taken up politically. In the lengthy debates about the Fair Work Bill and about the current award modernisation process, there has been very little reference, if any, to gender equality, decent work or to related international standards. ${ }^{49}$ There also remains some ambivalence in various articulations of the decent work agenda about the full extension of the same level of statutory entitlements, protections and benefits accorded to standard workers to all workers in need of protection. ${ }^{50}$ Further, while the importance of gender equality is explicit in elaborations of the decent work agenda, to date the focus has been on gender equality as one outcome of employment regulation rather than as a central rationale or driver of such regulation.

Nevertheless, I think the conception of gender equality at the heart of decent work can be used as a regulatory and policy starting point for a reframing of rights to gender equality in paid work that might be translated into tangible and sustainable improvements in women's status in and experience of paid employment. Leah Vosko argues that ensuring decent work for all means developing an alternative imaginary that addresses more fully the complex interplay between employment norms, gender relations and citizenship boundaries, which sees the realisation of decent work through gender equality. ${ }^{51}$ To this end, one of the key principles she proposes is 'global universal caregiving', building on Nancy Fraser's 'universal caregiver' and Eileen Applebaum's 'shared work/valued care' models. Gender equality and decent work thus require a redistribution of work between women and men and between the unemployed and the employed ${ }^{52}$ and, I would add, the underemployed.

\footnotetext{
47 Karl Klare, 'The Horizons of Transformative Labour and Employment Law' in Joanne Conaghan, Richard Fischl and Karl Klare (eds), Labour Law in an Era of Globalization: Transformative Practices and Possibilities, Oxford University Press, UK, 2004.

48 See Vosko, 'Decent Work'; Scheele, 'Gender and the Quality of Work'.

49 This is despite the Australian Council of Trade Unions (ACTU) endorsing a decent work policy for the first time at its July 2009 Congress (<http://www.actu.asn.au/Issues/DecentWork/default.aspx\#>).

50 Vosko, 'Decent Work' 19, 32.

51 Vosko, Precarious Employment and the Problem of SER-Centrism.

52 Scheele, 'Gender and the Quality of Work' 595, 608.
} 
With increasing international recognition of the limits of the so-called free market in ending discrimination, including sex discrimination, national governments are now grappling with the issue of re-regulation. ${ }^{53}$ Indeed, the failure of current regulatory models to meet the challenge of responding to the place of paid work and of workers in the new economy underpins a wholesale rethinking not only of the role of employment regulation, but also of the gender equality project and the role of international law and institutions within it. ${ }^{54}$ As Judy Fudge points out, the new economy with its heterogeneity and diversity need not intensify inequality and exclusion; it can also mean equality and inclusion by accommodating a range of different types of jobs and workers. ${ }^{55}$ It is therefore timely to start assessing the potential of the decent work agenda approach as a way of moving towards a more comprehensive realisation of the CEDAW goals for gender equality - something that Caroline Lambert's chapter takes up. The challenge is to move to an integrated legislative framework, policy and practice that meet the threefold approach of CEDAW to gender equality ${ }^{56}$

- to achieve full equality of women before the law and in public administration

- to improve the de facto position of women

- to address the prevailing gender relations and the persistence of genderbased stereotypes.

To be successful in advancing the position of women in paid work, this multilayered understanding of gender equality needs to be brought into the centre of the mainstream employment jurisdiction and not just left up to the $S D A$ or the EOWWA. The ILO's decent work agenda provides the basis of a framework to achieve this. The task ahead is to identify the central elements of an Australian integrated regulatory framework that could underpin progress to greater gender equality in paid work, including recognition of life outside paid work. ${ }^{57}$

\footnotetext{
53 Cornish, Ending Labour Market Gender Discrimination.

54 See Conaghan et al., Labour Law in an Era of Globalization; Fredman, Human Rights Transformed; Belinda Smith, 'It's About Time - For a New Approach to Equality' (2008) 36 Federal Law Review 117; Vosko, 'Decent Work'; Rikki Holtmaat, Catalysts for Change? Equality Bodies according to Directive 2000/43/EC, DirectorateGeneral for Employment, Social Affairs and Equal Opportunities, European Commission, Brussels, 2007.

55 Judy Fudge, ‘Equity Bargaining in the New Economy' (2006) 8 Just Labour 82.

56 See Rikki Holtmaat, Towards Different Law and Public Policy: The Significance of Article 5a CEDAW for the Elimination of Structural Gender Discrimination, Reed Business Information, The Hague, 2004.

57 An existing gender equality policy framework that the government could extend into the domestic policy context is that which underpins the Australian Agency for International Development (AusAID) program (see <http://www.ausaid.gov.au/publications/pdf/gender_policy.pdf $>$ ). Gender equality is stated to be 'an overarching principle of Australia's aid program'. This means that 'gender equality is integral to all Australian government aid policies, programs and initiatives'. This policy framework places emphasis on gender equality outcomes including the demonstration of progress towards the improved economic status of women and equal participation in decision making and leadership. In progress towards gender equality, the framework is designed to encourage strategic and well-targeted interventions, which are informed by operating principles such as: engaging with both men and women to advance gender equality; strengthening accountability mechanisms to increase effectiveness; and collecting and analysing information to improve gender equality
} 


\section{Bibliography}

\section{Books and articles}

Bacchi, Carol, 'The Seesaw Effect: Down Goes Affirmative Action, Up Comes Workplace Diversity' (2000) 5 Journal of Interdisciplinary Gender Studies 64.

Bennett, Laura, 'Women and Enterprise Bargaining: The Legal and Institutional Framework' (1994) 36 Journal of Industrial Relations 191.

Bosch, Gerhard, 'Towards a New Standard Employment Relationship in Western Europe?' (2004) 42 British Journal of Industrial Relations 617.

Braithwaite, Valerie, 'The Australian Government's Affirmative Action Legislation: Achieving Social Change through Human Resource Management' (1993) 15 Law and Policy 322.

Buchanan, John and Thornthwaite, Louise, Paid Work and Parenting: Charting a New Course for Australian Families, Australian Centre for Industrial Relations Research and Training, Sydney, 2001.

Burgess, John and Strachan, Glenda, 'Equal Employment Opportunity, Employment Restructuring and Enterprise Bargaining: Complementary or Contradictory?' (1998) 3 Journal of Interdisciplinary Gender Studies 23.

Burgess, John, Keogh, Paul, Macdonald, Duncan, Morgan, G. H., Strachan, Glenda and Ryan, Suzanne, Enterprise Bargaining in Three Female Dominated Workplaces in the Hunter, Employment Studies Research Paper No. 23, University of Newcastle, NSW, 1996.

Burgess, John, Sullivan, Anne and Strachan, Glenda, 'Australian Workplace Agreements, EEO and Family Friendly Arrangements in the Retail Sector' (2004) 4 Employment Relations Record 61.

Campbell, Iain, 'Australia: Institutional Changes and Workforce Fragmentation' in Sangheon Lee and Francois Eyraud (eds), Globalization, Flexibilization and Working Conditions in Asia and the Pacific, Chandros Publishing, Oxford, 2008.

results. Given the clear and unequivocal expectations Australia has of countries that receive Australian aid, it would behove the Australian Government to practice what it preaches within Australia itself. The federal government should insist that gender equality is integral to all Australian Government policies, programs and initiatives within Australia, with the appropriate mechanisms put in place to operationalise this commitment, including in employment regulation and policy. 
Campbell, Iain, Whitehouse, Gillian and Baxter, Janine, 'Australia: Casual Employment, Part-time Employment and the Resilience of the Male Breadwinner Model' in Leah Vosko, Martha MacDonald and Iain Campbell (eds), Gender and the Contours of Precarious Employment, Routledge, London, 2009.

Chalmers, Jenny, Campbell, Iain and Charlesworth, Sara, 'Part-Time Work and Caring Responsibilities in Australia: Towards an Assessment of Job Quality' (2005) 15 Labour \& Industry 41.

Chapman, Anna, 'Discrimination Complaint-Handling in NSW: The Paradox of Informal Dispute Resolution' (2000) 22 Sydney Law Review 321.

Charlesworth, Sara, Stretching Flexibility: Women and Working Time Arrangements in Enterprise Bargaining, Human Rights and Equal Opportunity Commission, Sydney, 1996.

Charlesworth, Sara, 'The Overlap of the Federal Sex Discrimination and Industrial Relations Jurisdictions: Intersections and Demarcations in Conciliation' (2003) 6 Australian Journal of Labor Economics 559.

Charlesworth, Sara, Hall, Philippa and Probert, Belinda, Drivers and Contexts of Equal Employment Opportunity and Diversity Action in Australian Organisations, RMIT Publishing, Informit E-library, Melbourne, 2005.

Charlesworth, Sara and Macdonald, Fiona, 'The Unpaid Parental Leave Standard: What Standard?', Refereed Proceedings of the 21st Conference of Association of Industrial Relations Academics of Australia and New Zealand, Melbourne, 6-8 February 2008.

Conaghan, Joanne, 'Intersectionality and UK Equality Initiatives' (2007) 23 South African Journal on Human Rights 317.

Conaghan, Joanne, Fischl, Richard and Klare, Karl (eds), Labour Law in an Era of Globalization: Transformative Practices and Possibilities, Oxford University Press, UK, 2004.

Cornish, Mary, 'Closing the Global Gender Pay Gap: Securing Justice for Women's Work' (2007) 28 Comparative Labour Law and Policy Journal 219.

Cornish, Mary, Ending Labour Market Gender Discrimination: Bringing Gender Mainstreaming into Parliamentary Laws and Institutions, Presentation to Women \& Work Conference of International Parliamentary Unions, Geneva, 6 December 2007.

Dickens, Linda, 'The Road is Long: Thirty Years of Equality Legislation in Britain' (2007) 45 British Journal of Industrial Relations 463. 
French, Erica, 'Approaches to Equity Management and their Relationship to Women in Management' (2001) 12 British Journal of Management 267.

French, Erica and Strachan, Glenda, 'Equal Opportunity Outcomes for Women in the Finance Industry in Australia: Evaluating the merit of EEO Plans' (2007) 45 Asia Pacific Journal of Human Resources 314.

Fredman, Sandra, Discrimination Law, Oxford University Press, UK, 2002.

Fredman, Sandra, 'Changing the Norm: Positive Duties in Equal Treatment Legislation' (2005) 12 Maastricht Journal of European and Comparative Law 369.

Fredman, Sandra, Human Rights Transformed: Positive Duties and Positive Rights, Oxford University Press, UK, 2008.

Fudge, Judy, 'Equity Bargaining in the New Economy' (2006) 8 Just Labour 82.

Fudge, Judy and Owens, Rosemary, Precarious Work, Women and the New Economy: The Challenge to Legal Norms, Hart Publishing, Oxford, 2006.

Gaze, Beth, 'The Sex Discrimination Act after Twenty Years: Achievements, Disappointments, Disillusionment and Alternatives' (2004) 19 University of New South Wales Law Journal 57.

Green, Francis, Demanding Work: The Paradox of Job Quality in the Affluent Economy, Princeton University Press, NJ, 2005.

Hall, Philippa and Fruin, Di, 'Gender Aspects of Enterprise Bargaining: The Good, the Bad and the Ugly' in D. E. Morgan (ed.), Dimensions of Enterprise Bargaining and Organizational Relations, UNSW Studies in Australian Industrial Relations No. 36, University of New South Wales, Sydney, 1994.

Holtmaat, Rikki, Towards Different Law and Public Policy: The Significance of Article 5a CEDAW for the Elimination of Structural Gender Discrimination, Reed Business Information, The Hague, 2004.

Holtmaat, Rikki, Catalysts for Change? Equality bodies according to Directive 2000/43/EC, Directorate-General for Employment, Social Affairs and Equal Opportunities, European Commission, Brussels, 2007.

Holtmaat, Rikki and Tober, Christa, 'CEDAW and the European Union's Policy in the Field of Combating Gender Discrimination' (2005) 12 Maastricht Journal of European and Comparative Law 399.

Hunter, Rosemary, 'The Mirage of Justice: Women and the Shrinking State' (2002) 16 Australian Feminist Law Journal 53. 
Hunter, Rosemary and Leonard, Alice, The Outcomes of Conciliation in Sex Discrimination Cases, Working Paper No. 8, Centre for Employment and Labour Relations Law, Faculty of Law, University of Melbourne, Vic., 1995.

Klare, Karl, 'The Horizons of Transformative Labour and Employment Law' in Joanne Conaghan, Richard Fischl and Karl Klare (eds), Labour Law in an Era of Globalization: Transformative Practices and Possibilities, Oxford University Press, UK, 2004.

Lee, Sangheon, McCann, Deirdre and Messenger, John, Working Time Around the World: Trends in Working Hours, Laws, and Policies in a Global Comparative Perspective, Routledge, Oxford, 2004.

Lowe, Graham, 21st Century Job Quality: Achieving What Canadians Want, Research Report W/37 Work and Learning, Canadian Policy Research Networks, Toronto, Ont, 2007.

McDonald, Paula, Backstrom, Sandra and Dear, Kerriann, 'Reporting Sexual Harassment: Claims and Remedies' (2008) 46 Asia Pacific Journal of Human Resources 173.

Murray, Jill, Working Conditions Laws in an Integrating World Project: Australia, Unpublished paper prepared for the International Labour Organisation, Geneva, 2009.

Owens, Rosemary, 'The Peripheral Worker: Women and the Legal Regulation of Outwork' in Margaret Thornton (ed.), Public and Private: Feminist legal debates, Oxford University Press, Melbourne, 1995.

Owens, Rosemary, 'Decent Work for the Contingent Workforce in the New Economy' (2002) 15 Australian Journal of Labour Law 209.

Peetz, David, 'Collateral Damage: Women and the WorkChoices Battlefield' (2007) 33 Hecate 61.

Pocock, Barbara, The Work-Life Collision: What Work is doing to Australians and what to do about it, Federation Press, Sydney, 2003.

Pocock, Barbara, Elton, Jude, Preston, Alison, Charlesworth, Sara, Macdonald, Fiona, Baird, Marian, Cooper, Rae and Ellem, Bradon, 'The Impact of "Work Choices" on Women in Low paid Employment in Australia: A Qualitative Analysis' (2008) 50 Journal of Industrial Relations 475.

Preston, Alison and Jefferson, Therese, 'Trends in Australia's Gender Wage Ratio' (2007) 18 Journal of Labour and Industry 69. 
Preston, Alison and Whitehouse, Gillian, 'Gender Differences in Occupation of Employment within Australia' (2004) 7 Australian Journal of Labour Economics 309.

Scheele, Alexandra, 'Gender and the Quality of Work: An Overview of European and National Approaches' (2007) 13 Transfer 595.

Sheridan, Alison, 'Affirmative Action in Australia - Employment Statistics can't tell the Whole Story' (1995) 10 Women in Management Review 26.

Smith, Belinda, 'From Wardley to Purvis-How Far has Australian AntiDiscrimination Law come in 30 Years?' (2007) 21 Australian Journal of Labour Law.

Smith, Belinda, 'It's About Time-For a New Approach to Equality' (2008) 36 Federal Law Review 117.

Smith, Mark, Burchell, Brendan, Fagan, Colette and O'Brien, Catherine, 'Job Quality in Europe' (2008) 39 Industrial Relations Journal 586.

Smith, Meg and Ewer, Peter, The Position of Women in the National Training Reform Agenda and Enterprise Bargaining, Department of Education, Employment and Training, Australian Government Printing Service, Canberra, 1995.

Smith, Meg and Lyons, Michael, '2020 Vision or 1920s Myopia? Recent Developments in Gender Pay Equity in Australia' (2007) 13 International Employment Relations Review 27.

Strachan, Glenda and Burgess, John, 'W(h)ither Affirmative Action Legislation in Australia?' (2000) 5 Journal of Interdisciplinary Gender Studies 46.

Strachan, Glenda and French, Erica, 'Equal Opportunity: Disentangling Promise from Achievement', Proceedings of the Gender, Work and Organisation: 5th Biennial International Interdisciplinary Conference, Keele University, UK, 2007.

Thornton, Margaret, The Liberal Promise: Anti-Discrimination Legislation in Australia, Oxford University Press, UK, 1990.

Thornton, Margaret, 'Auditing the Sex Discrimination Act' in Marius Smith (ed.), Human Rights 2004: The Year in Review, Castan Centre for Human Rights Law, Monash University, Melbourne, 2005.

Vosko, Leah, “"Decent Work": The Shifting Role of the ILO and the Struggle for Global Social Justice' (2002) 2 Global Social Policy 19. 
Vosko, Leah, Precarious Employment and the Problem of SER-Centrism: Regulating for "Decent Work", Paper given to the Regulating for Decent Work-Innovative labour regulation in a turbulent world Conference, International Labour Organisation, Geneva, 8 July 2009.

Walby, Sylvia, Gender (In)Equality and the Future of Work, Equal Opportunities Commission, Manchester, 2007.

Whitehouse, Gillian, ‘Recent Trends in Pay Equity: Beyond the Aggregate Statistics' (2001) 43 Journal of Industrial Relations 66.

\section{Legislation}

Fair Work Act 2009 (Cth)

Industrial Relations Reform Act 1993 (Cth)

Sex Discrimination Act 1984 (Cth)

Workplace Relations Act 1996 (Cth)

\section{Case}

Australian Industrial Relations Commission, Award Modernisation-Statement, 12 September, 2008, [2008] AIRCFB 717, Giudice J, Lawler VP, Watson VP, Watson SDP, Harrison SDP, Acton SDP and Smith C., <http://www.fwa.gov.au/ decisionssigned/html/2008aircfb717.htm>

\section{Reports and miscellaneous primary sources}

Australian Bureau of Statistics, Australian Labour Market Statistics, July 2009, Cat. No. 6105, Australian Bureau of Statistics, Canberra, 2009.

European Commission, Employment in Europe 2008, European Communities, Luxembourg, 2008.

House of Representatives Standing Committee on Employment and Workplace Relations, Making it Fair: Pay Equity and Associated Issues related to increasing Female Participation in the Workforce, Commonwealth of Australia, Canberra, 2009.

Human Rights and Equal Opportunity Commission, Annual Report 2007-2008, Human Rights and Equal Opportunity Commission, Sydney, 2008. 
Human Rights and Equal Opportunity Commission, Sexual Harassment: Serious Business.Results of the 2008 Sexual Harassment National Telephone Survey, Human Rights and Equal Opportunity Commission, Sydney, 2008.

International Labour Organisation, Decent Work: A Report of the DirectorGeneral, 89th Session of the International Labour Organisation, Geneva, 1999.

International Labour Organisation, $A B C$ of Women Workers' Rights and Gender Equality, Second edition, International Labour Organisation, Geneva, 2007.

KPMG, Review of the Equal Opportunity for Women in the Workplace Act 1999: Consultation Report, KPMG, Melbourne, 2010.

Senate Standing Committee on Legal and Constitutional Affairs, Report on the Effectiveness of the Commonwealth Sex Discrimination Act 1984 in Eliminating Discrimination and Promoting Gender Equality, Parliament of Australia, Canberra, 2008. 